\title{
ANALYSIS OF MAKING-DO WASTE AT CONSTRUCTION SITE IN FORTALEZA, CEARÁ, BRAZIL
}

\author{
Éden Malveira dos Santos ${ }^{1}$, Amanda Daniel Fontenele ${ }^{2}$, Amanda Moreira Lima \\ Machado $^{3}$, José de Paula Barros Neto ${ }^{4}$, and Tatiana Gondim do Amaral ${ }^{5}$
}

\begin{abstract}
The competitive market in the construction sector leads companies to develop actions in the construction processes to prevent waste. Making-do waste is considered as the waste originated from a situation in which a task iniciates without the necessary resources, such as materials, labor or equipment, or when these items are not suitable for carrying out an activity. The study of this type of waste makes it possible to optimize task planning and control and, thus, to reduce other kinds of waste. Therefore, this paper aims to analyze how waste from making-do affects construction sites in three construction companies in Fortaleza, Brazil, classifying it into categories, identifying its possible causes and analyzing its impacts. This paper also presents a risk analysis of the identified making-do waste.
\end{abstract}

\section{KEYWORDS}

Making-do, improvisation, waste, construction sites

\section{INTRODUCTION}

The construction industry is one of the sectors that contributes significantly to the Brazilian economy. However, this industry frequently faces problems of waste, low productivity, delays, restricted safety, limited working conditions and insufficient quality, many of them related to waste in the construction processes (Koskela, 2004).

According to State of Ceará Government (2019), in the first quarter of 2019 the industry sector closed with a drop of $2.42 \%$ in the Gross Domestic Product (GDP) when compared to the same period in 2018, a direct reflection of the negative indices in all segments, amongst them the construction sector, with a $0.28 \%$ drop. According to the Brazilian Institute of Geography and Statistics - IBGE (2017), between 2014 and 2017 there was a drop of more than R\$ 3.9 billions (U\$ 0.78 billion) in the value of the real

1 Master Student, Department of Structural and Civil Construction, Federal University of Ceará, Brazil, eden_malveira@hotmail.com, orcid.org/0000-0001-5911-7113

2 Master Student, Department of Structural and Civil Construction, Federal University of Ceará, Brazil, amanda_fontenele@alu.ufc.br, orcid.org/0000-0001-5152-5470

3 Master Student, Department of Structural and Civil Construction, Federal University of Ceará, Brazil, amandamlmachado@gmail.com, orcid.org/0000-0003-2522-2761

4 Full Professor, Department of Structural and Civil Construction, Federal University of Ceará, Brazil, barrosneto@gercon.ufc.br, orcid.org/0000-0001-5131-4593

5 Associated Professor, Department of Environmental and Civil Engineering, Federal University of Goiás, Brazil, tatianagondim@ufg.br, orcid.org/0000-0002-9746-4025 
estate market. Given the current economic scenario, alongside the increasing degree of competition amongst companies, the increasing level of demand from consumers and reduced availability of financial resources for project development, companies started to seek more frequently ways to reduce processes that do not add value to the final product and result mainly in delayed tasks and increased costs (Rosenblum et al. 2008). This search for continuous improvement meets one of lean construction principles.

Based on lean production philosophy, the concept of waste includes an occurrence of material waste and the execution of an unnecessary task, which generates additional costs but do not add value to the product (Formoso et al. 1997). Thus, the elimination of waste in the construction industry allows, mainly, the increase of productivity and control in construction site.

In addition to the waste categories identified by Ohno (1997) and Formoso et al. (1997), Koskela (2004) suggests that the making-do could be an addition to them. According to the researcher, the making-do waste in the construction sector is considered as the waste originated from a situation in which a task iniciates without the necessary resources, such as materials, labor or equipment, or when these items are not suitable for the execution of an activity. This waste leads to a reduction in quality, lack of terminality and rework of tasks.

The study of making-do waste is being discussed since the first conceptualization by Koskela (2004) and was disseminated in Brazilian literature by authors such as Sommer (2010), Formoso et al. (2011), Fireman et al. (2013) and Leão (2014). With respect to the study by Ronen (1992), there are management aspects in Machado (2003) and Santos (2004) that make production feasible by reducing or avoiding what is now conceptualized as making-do. Therefore, any investigation about the nature, causes, and main consequences of waste by making-do in the construction industry becomes relevant (Formoso et al. 2017).

In Brazil, research related to the application of this topic was carried out in the states of Goiás, Rio Grande do Sul and Sergipe. Hence, it is favorable to apply the study in the city of Fortaleza, since it is one of the Brazilian cities in which there is research focused on lean philosophy. The knowledge gap regarding the dissemination of this theme in construction sites was verified, because there are high indexes regarding this waste in production sites (Santos and Santos 2017).

Therefore, knowing that studies of making-do contribute to improve the planning and control of tasks and to disseminate this subject in construction sites, the present work aims to investigate and analyze the waste by making-do in three construction companies in Fortaleza, classifying them and identifying the possible generated impacts.

\section{MAKING-DO AS A WASTE CLASSIFICATION}

Emmitt et al. (2012) question the term "good enough", commonly used in construction. Unlike in manufacturing, construction workers concentrate on finishing the product, and work management is done so that the final product presents an acceptable standard.

In this context, theories evolve and new ones arise. In lean construction, no doubt an important addition was the designation by Koskela (2004) of a new category of waste, making-do, expanding the widely known and referenced list of Ohno (1997) and Shingo (1989).

In the construction sector, high production costs are related to waste in construction processes (Viana et al. 2012), which should be interpreted as any inefficiency in the use of equipment, materials, labor and capital (Formoso et al. 1997). Hence, the elimination 
of waste has been the main focus of companies that have adopted the lean construction philosophy (Sommer 2010; Barbosa et al. 2013).

Ohno (1997) proposed a classification with seven types of waste for better visualization and understanding of their impacts on production, thus being able to counter them in a simultaneous and articulated manner, namely: waste of overproduction, waste of waiting, waste of transportation, waste of the processing itself, waste of stock, waste of motion and waste of making defects. Formoso et al. (1997) propose the addition of another category: waste of substitution.

Koskela (2004) presents a new variety of waste called making-do, defined as the waste that occurs when a task starts without all the necessary resources, or when it is continued even in the absence of one or more resources. Cunha (2004) treats making-do as a synonym for bricolage, meaning the invention of resources based on what is available to solve problems in advance.

The making-do stands out for triggering other wastes, such as poor safety, reduced quality, work in progress and rework (Sommer 2010; Formoso et al. 2011; Fireman et al. 2013). Some categories of making-do waste were reported by Sommer (2010) and expanded by Fireman (2012) and Leão (2014), totaling, so far, eight categories of makingdo waste, shown in Table 1.

Table 1: Categories of making-do waste

\begin{tabular}{ccc}
\hline Category & Description & Authors \\
\hline Access/movement & $\begin{array}{c}\text { Relative to space, environment or position to } \\
\text { perform the tasks }\end{array}$ & Sommer (2010) \\
\hline $\begin{array}{c}\text { Adjustment of } \\
\text { component }\end{array}$ & $\begin{array}{c}\text { Unexpected adjustment of construction } \\
\text { components or elements to perform tasks }\end{array}$ & Sommer (2010) \\
\hline Working area & $\begin{array}{c}\text { Reference to the work area or the support area } \\
\text { during the activities performed }\end{array}$ & Sommer (2010) \\
\hline Storage & $\begin{array}{c}\text { Organization of materials or components in } \\
\text { places not prepared for their receipt }\end{array}$ & Sommer (2010) \\
\hline Equipment/Tools & Creation or adaptation for use during activities & Sommer (2010) \\
\hline Sater and electricity & Existence of infrastructure to perform tasks. & Sommer (2010) \\
\hline Protection & Use of protection systems & Sommer (2010) \\
\hline Sequencing & Alteration of the construction process & Fireman (2012); \\
\hline
\end{tabular}

Formoso et al. (2017) state that waste due to making-do tend to be high in construction sites, since the poor management of upstream flows (for example, material supply, design, space infrastructure setup, equipment setup) makes it impossible to complete tasks included in short-term plans due to lack of inputs.

Sommer (2010) presented categories of prerequirement that, if not met, could cause the making-do, shown in Table 2. The unavailability of resources can result in effects such as interruption of work or improvisations (Formoso et al. 2011). Ronen (1992) and Grosfled-Nir and Ronen (1998) present two broad categories of making-do consequences: technical, which refers to the time, cost and quality of the task; and behavioral, which refers to productivity loss of the workers who perform the task. Authors such as Koskela (2004) and Sommer (2010) studied some impacts caused by making-do waste, such as reduced productivity, reduced motivation, material waste, rework, poor safety, and reduced quality. Along with these, Fireman (2012) added an impact called unfinished work. Another one reported by Ohno (1997), as a consequence of any type of waste, is the increase in costs that do not add value to the final product. Formoso et al. (2011) and 
Fireman et al. (2013) affirm that the impact of making-do on the cycle time of processes is inevitable, since work is interrupted and new mobilization and demobilization operations are required, in addition to new processing, directly interfering with the planPd schedule.

Table 2: Necessary prerequirement for starting an activity

\begin{tabular}{|c|c|c|}
\hline Prerequirement & Description & Authors \\
\hline Information & Availability of adequate information regarding work plans. & $\begin{array}{l}\text { Sommer (2010); } \\
\text { Koskela (2004) }\end{array}$ \\
\hline $\begin{array}{l}\text { Materials and } \\
\text { components }\end{array}$ & $\begin{array}{l}\text { Availability of materials and components with quality, } \\
\text { quantity, and within the specifications of the project and } \\
\text { standards. }\end{array}$ & $\begin{array}{l}\text { Sommer (2010); } \\
\text { Koskela (2004) }\end{array}$ \\
\hline Labor & $\begin{array}{l}\text { Availability of necessary human resources, in number, or } \\
\text { qualification. }\end{array}$ & $\begin{array}{l}\text { Sommer (2010); } \\
\text { Koskela (2004) }\end{array}$ \\
\hline Equipment/tools & Availability and functioning of activities. & $\begin{array}{l}\text { Sommer (2010); } \\
\text { Koskela (2004) }\end{array}$ \\
\hline Space & $\begin{array}{l}\text { Availability of work area, circulation or storage of } \\
\text { materials. }\end{array}$ & $\begin{array}{l}\text { Sommer (2010); } \\
\text { Koskela (2004) }\end{array}$ \\
\hline $\begin{array}{l}\text { Interdependent } \\
\text { tasks }\end{array}$ & $\begin{array}{l}\text { Activities with high interdependence compromise the } \\
\text { execution of subsequent tasks. }\end{array}$ & $\begin{array}{l}\text { Sommer (2010); } \\
\text { Koskela (2004) }\end{array}$ \\
\hline $\begin{array}{c}\text { External } \\
\text { conditions }\end{array}$ & Wind, rain or extreme temperatures. & $\begin{array}{l}\text { Sommer (2010); } \\
\text { Koskela (2004) }\end{array}$ \\
\hline Installations & $\begin{array}{c}\text { Availability of provisional electrical and hydraulic } \\
\text { installations, site security facilities, scaffolding, closures, } \\
\text { and isolation of stock areas. }\end{array}$ & Sommer (2010) \\
\hline
\end{tabular}

\section{RESEARCH METHOD}

This research is an exploratory and descriptive study to identify events, qualitative and/or quantitative, that resulted in making-do waste. It was carried out through surveys at construction sites of three construction companies in Fortaleza, Brazil.

Based on the work developed by Koskela (2004), Formoso et al. (2011) and Fireman (2012), Sommer (2010) proposed a method of identifying making-do in construction sites, which is represented in Figure 1.

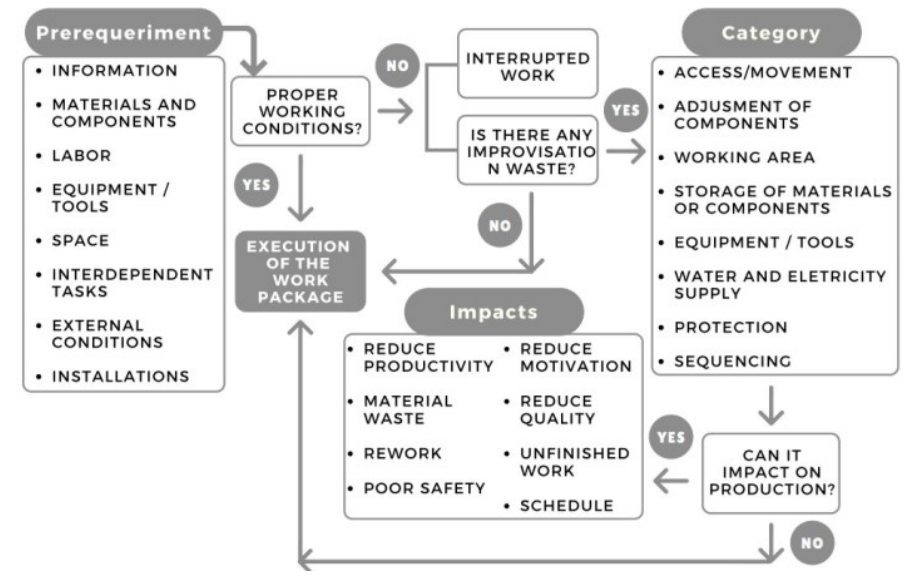

Figure 1: Methods for identifying and measuring making-do waste (adapted from Sommer (2010))

\section{DATA COLLECTION}

A comprehensive data collection was carried out between April and September of 2019, adopting research tools such as surveys, interviews, photographic records and analysis of blueprints and documents. The surveys were applied to characterize the construction 
companies, the tasks and to investigate their planning process. The interviews were done with task managers and technicians. Construction sites were in different stages, such as structure, masonry, installation, and finishing stage. The characterization of the construction companies is shown in Table 3.

Table 3: Characterization of construction companies

\begin{tabular}{cccc}
\hline Company & A & B & C \\
\hline Description & $\begin{array}{c}\text { High standard } \\
\text { multifamily building }\end{array}$ & Commercial center & $\begin{array}{c}\text { High standard } \\
\text { multifamily building }\end{array}$ \\
\hline $\begin{array}{c}\text { Current phase of } \\
\text { execution }\end{array}$ & $\begin{array}{c}\text { Structure and } \\
\text { installations }\end{array}$ & $\begin{array}{c}\text { Masonry, Structure and } \\
\text { installations }\end{array}$ & $\begin{array}{c}\text { Finishing and } \\
\text { installations }\end{array}$ \\
\hline $\begin{array}{c}\text { Total execution } \\
\text { area }\left(\mathrm{m}^{2}\right)\end{array}$ & $26.341,54$ & $11.062,88$ & $12.706,83$ \\
\hline Type of labor & $\begin{array}{c}\text { Own and } \\
\text { Outsourced }\end{array}$ & Own & Own and Outsourced \\
\hline Number of stories & 38 & 6 & 28 \\
\hline
\end{tabular}

After this characterization, structured surveys were applied to engineers and supervisors, to investigate making-do waste related to construction processes and planning. In addition to the surveys, unstructured interviews were conducted with construction supervisors and other technical professionals to verify related documentation, such as designs, lists of individual and collective protective equipment, and presence of employment verification and control sheets.

Finally, visits were made in the construction sites. The main sources of evidence collected by direct observation were: improvisations made by labor due to lack of inputs by planning; work environment conditions that could require some kind of improvisation by the workforce, which may interfere in one or more tasks. They are the two main points of events that generate waste by making-do (Formoso et al. 2017).

\section{DATA PROCESSING}

To finish the data collection phase, the data processing step was initiated with the organization of a database, through the creation of spreadsheets with the support of Excel software. Each identified phenomenon was characterized, with its description, cause, the team responsible for the service, stage, and substep of the service performed. Figure 2 shows the data organization.

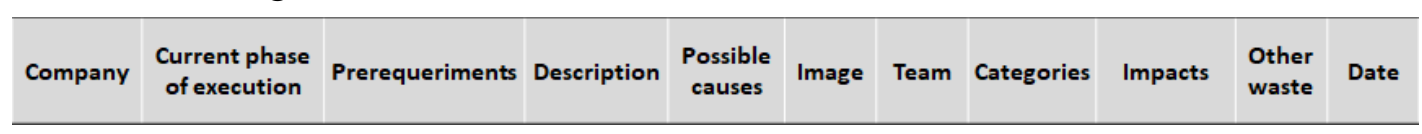

Figure 2: Database model

The analysis of each item started with the classification in categories, defined by Sommer (2010), Fireman (2012), and Leão (2014), and specified beforehand in Table 1. The prerequirements, defined by Sommer (2010) and Koskela (2004), were detailed earlier in Table 2. Besides, it was necessary to analyze the relation of impacts generated by each event, whose classification is important and fundamental to analyze the results, observing parameters that influence both the construction and the final quality of products. Impacts used to categorize the phenomena were defined by Koskela (2004), Sommer (2010), Fireman (2012), Ohno (1997), Formoso et al. (2011) and Fireman et al. (2013). Thus, it was possible to achieve a better understanding of the influence of each listed phenomenon.

To refine the results, according to the studies by Fireman (2012), a risk analysis was adopted, aiming to provide information that indicated priorities and supported the choice of corrective actions. The risk analysis, adapted from Saurin (2002) by Fireman (2012), 
in Figure 3, used subjectivity to assess parameters of making-do waste and its probability of occurrence, creating three priority zones, divided by colors: High priority - dark gray, Intermediate priority - light gray, Low priority - white.

According to researchers, the probability criteria was classified according to the comparison of occurrence of making-do waste related to other wastes recorded in the observations, using a range from unlikely to frequent. The severity evaluation is regarding the comparison between that impact and other ones, that is, if the impact of an observed waste is considered greater than that of other wastes, it would be "Very High" (Figure 3).

\begin{tabular}{|c|c|c|c|c|c|}
\hline \multirow{2}{*}{ PROBABILITY } & \multicolumn{4}{|c|}{ SEVERITY } \\
\hline A - Unlikely & Very High - I & High - II & Moderate - III & Low - IV & Very Low - V \\
\hline B- Extremely & & & & \\
remote & & & & \\
C- - Remote & & & & \\
\hline D - Probable & & & & \\
\hline E - Frequent & & & & \\
\hline
\end{tabular}

Figure 3: Matrix for risk assessment using severity and probability parameters (adapted from Fireman (2012))

\section{RESULTS}

In this paper, the number of making-do events identified was relatively high. This resonates with results of previous studies, which pointed out that numbers of waste tend to be reasonably high in the construction industry, regardless of the category of waste being investigated (Horman and Kenley 2005; Formoso et al. 2017).

After data collection, the classification of cases identified in each construction company was performed. Each case was classified according to categories of making-do waste (Table 1). Figure 4 shows the percentage of categories of making-do waste obtained in the three construction companies analyzed. The three most recurrent categories observed were: adjustment of component, sequencing and protection. Company A shows sequencing as the highest percentage $(28.6 \%)$, whereas companies $\mathrm{B}$ and $\mathrm{C}$ have the adjustment of component as the main category of making-do waste, $35.3 \%$ and $58.3 \%$, respectively. The category of wastes to "adjustment of component" was observed in different situations: change of specified material in the project and reuse of old or damaged parts.

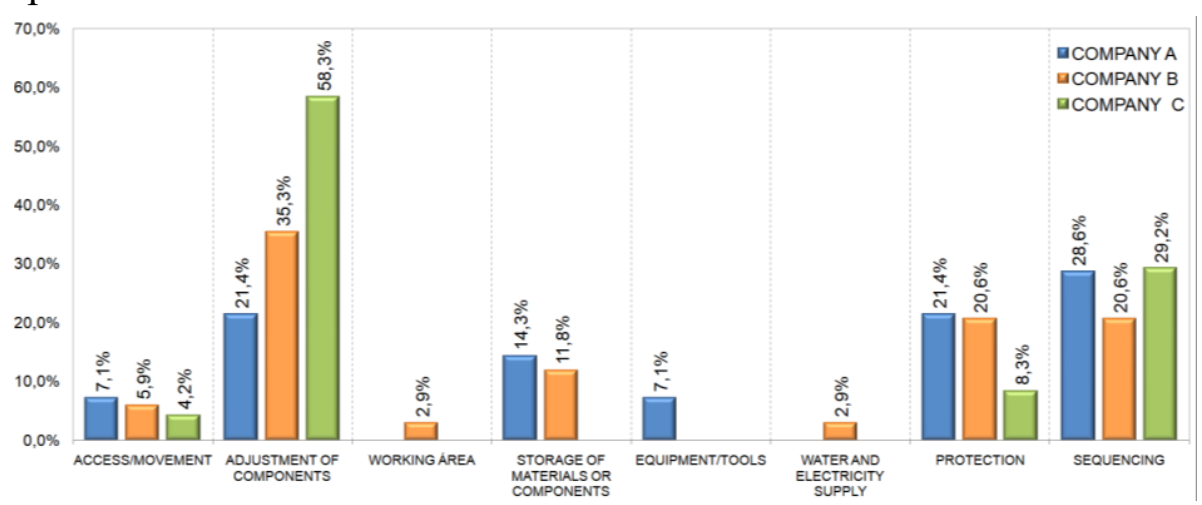

Figure 4: Categories of making-do waste for each construction company

These events could have as a cause, most of the time, the complacency of the technical crew when starting activities in the absence of adequate components for its execution. About sequencing, this is mainly related to planning for the completion of activities, especially those that do not influence the critical path. In the case of waste due to 
protection, the main problem found was the lack of integration between engineering and safety teams, especially at the level of advanced planning. According to Saurin et al. (2004), previous studies on the Last Planner System ${ }^{\circledR}$ pointed out a large percentage of restrictions related to safety at construction sites.

The next step was to identify the prerequirements, described in Table 2, responsible for the origin of the identified cases of making-do waste. Figure 5 shows the frequency of each prerequirement within the analyzed cases of the three construction companies. The most frequent prerequeriment is "materials and components", with company $\mathrm{C}$ having the highest percentage of $83.3 \%$, company B (70.6\%), and company A $(64.3 \%)$.

It is also noticed that, although companies $\mathrm{A}$ and $\mathrm{C}$ present high values in this prerequirement, they were not influenced by a significant number of other prerequirement in the generation of waste. The identified cases of Company B had their origins classified in almost all the prerequirement, though with low frequencies. Therefore, through visits and interviews with the technical team of each construction company, it was found that companies $\mathrm{A}$ and $\mathrm{C}$ have well-defined planning in the short and medium-term, while Company B does not present satisfactory planning methods, which justifies the variation and the occurrence of wastes related to a greater number of prerequirement. These results reinforce Sommer's (2010) conception when stating that wastes are associated with the management of prerequirement, impacting on production reliability.

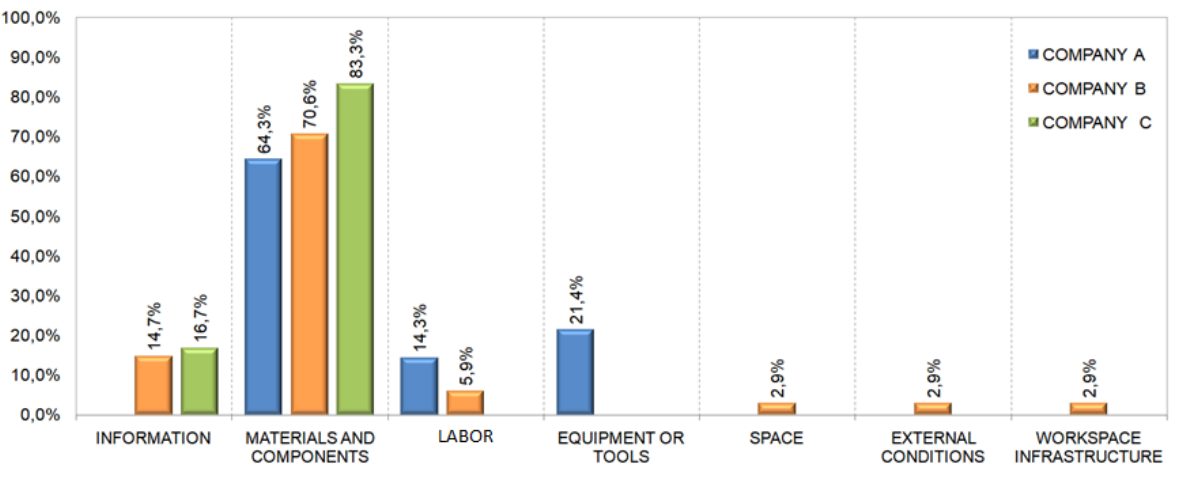

Figure 5: Causes of making-do waste for each construction company

Then, impacts generated by each case of making-do waste were identified. As mentioned above, this type of waste generates impacts that bring technical, financial, and behavioral consequences. Analysis of main impacts, resulting from the making-do waste identified in each construction company, is represented in Figure 6. Through it, it was observed that the highest incidence rate in Company A was the "reduced quality", representing $28.6 \%$ of data. This index can cause other impacts, such as rework, labor losses and material losses (Santos and Santos 2017). It was characterized due to problems in materials, equipment and construction processes identified during visits and interviews. Concrete placement failure resulting from use of aggregates larger than specified or difficulties during vibration phase and deformations in the slab resulted from the use of struts with lower resistance are examples of the problems encountered due to the lack of supervision during purchase phase of inputs and failure to monitor services. In Company B, the greatest impact was related to "poor safety", with $26.5 \%$, which was characterized by problems in the organization of the construction site and, mainly, by the lack of performance by the safety team. The absence of signaling and openings in the guardrail were observed to validate these arguments. 
For Company C, "rework" stood out as the main consequence of making-do waste, with $87.5 \%$. This high percentage value can be explained due to the stage of the construction. Since it was in the finishing phase, most of events identified were related to irregularities in coatings and installations, which needed to be corrected and redone. According to Love (2002), rework can influence both the performance and productivity of organizations, in addition to affecting the cost and schedule of processes.

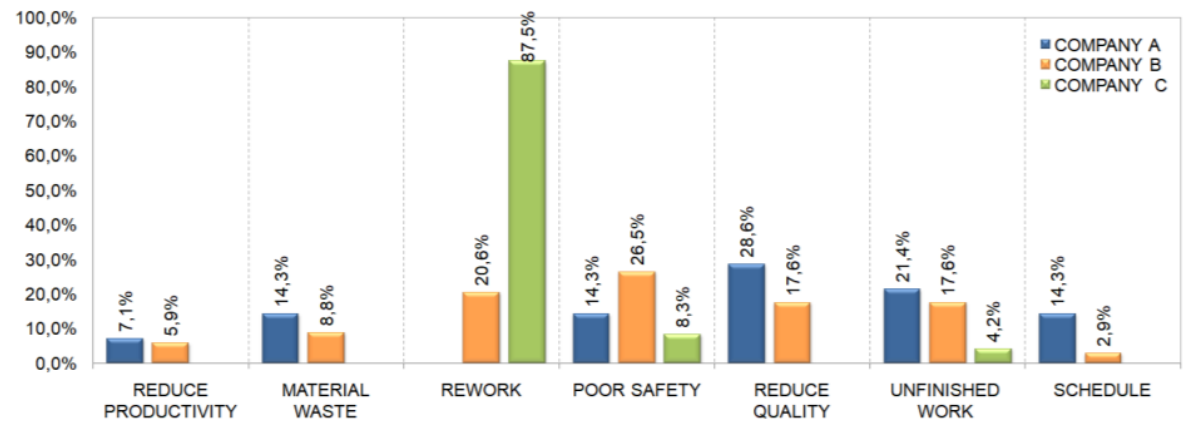

Figure 6: Possible impacts of making-do for each construction company

According to the execution phases of analyzed construction companies - structure, masonry, finishing and installations - it was possible to identify the main categories of making-do wastes (according to Table 1) in each one, which are presented in Figure 7. In addition to execution stages, categories of making-do waste arising from the management part, which covers engineering, safety and administrative sectors, were analyzed. Through this categorization, it was observed that the highest occurrence amongst all stages refers to adjustment of component, differing only from the managerial stage, where the most recurrent category is protection.

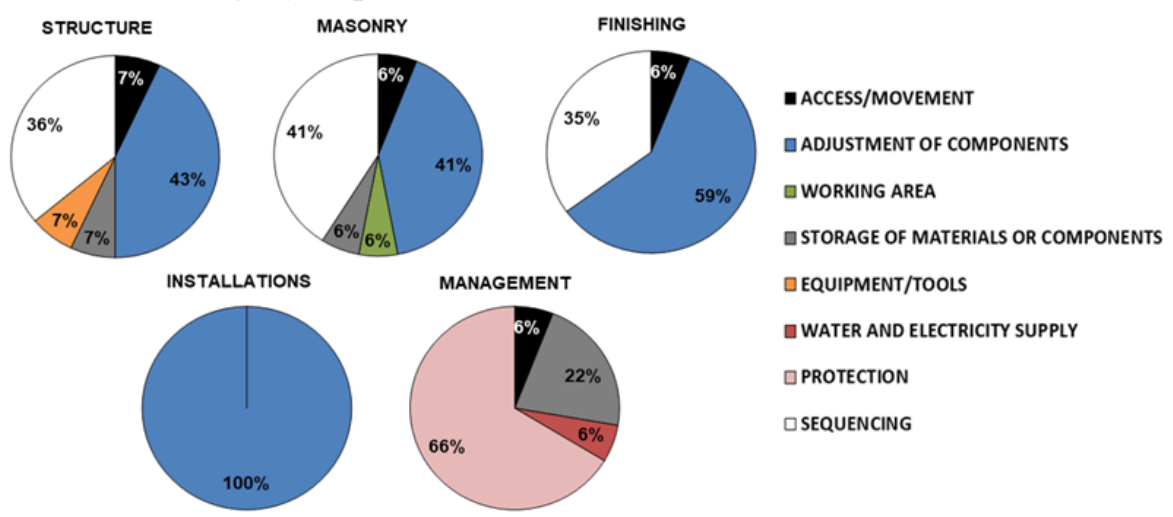

Figure 7: Categories of making-do wastes by stages of execution

In the structure phase, the most frequent categories of waste were "adjustment of component" with $43 \%$ and "sequencing" with $36 \%$. The fact that beams and flagstone are drilled after concreting results in wastes due to adjustment of component, and the failure to finish concreting structural parts generates a waste of sequencing. In masonry, the "adjustment of component" and "sequencing" were equal to $41 \%$. The cutout of the finished plaster for application of the waterproofing system is an example of waste due to component adjustment. The start of the mortar without the finished masonry is shown as a waste of sequencing.

Finally, the "adjustment of component" represents 59\% of occurrence. An example of this waste was the cutting of the lining of plaster for the installation of the gas flue pipe. In the installations, $100 \%$ of wastes observed are due to "adjustment of component": the existing pipes in the leisure area were altered due to the lack of project compatibility. In 
the management stage, the most recurrent category was protection, with $67 \%$. One fact observed was the lack of action by the safety team in placing guardrails in potential accident places.

Another point to be analyzed is the relation between execution phases of construction sites and the origin of identified cases of making-do wastes ( prerequirement), represented in Figure 8. The absence of prerequirement in an organization contributes to appearance of making-do waste and, due to the fact that the analyzed constructions were in different execution stages, it was decided to verify which are the main prerequirement not met in each stage. It is worth mentioning that, similarly to previous analysis, the management stage was also analyzed.
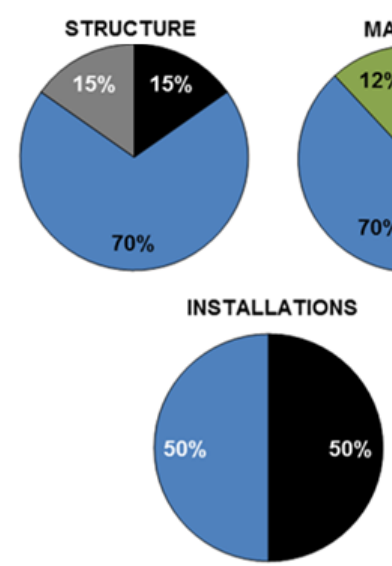
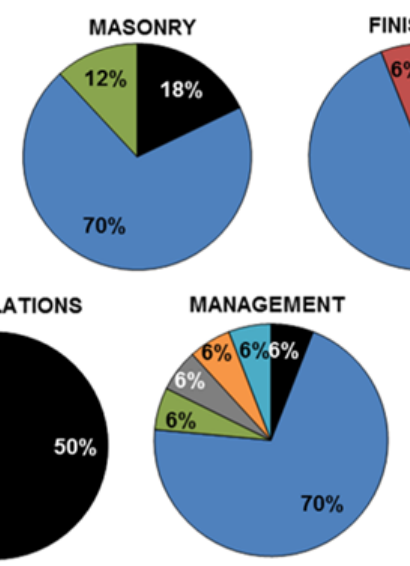

- INFORMATION

¿MATERIALS AND COMPONENTS

口LABOUR

IEQUIPMENT OR TOOLS

口SPACE

IEXTERNAL CONDITIONS

IWORKSPACE INFRASTRUCTURE

Figure 8: Causes of making-do wastes by stages of execution: prerequirement

It is clear, therefore, that failure to meet the prerequeriment "materials and components" was the main cause of making-do waste in most stages, except in the installations. In the structural phase, the lack of this prerequeriment summed $64 \%$, an example was the change of coarse aggregate in the concrete manufacturing. In masonry, "materials and components" totaled $71 \%$ of the absence of prerequirement, the acceptance of defective ceramic brick pieces was one of the observed situations. In the finishing stage, this is represented by $94 \%$, mainly due to the use of faulty coating pieces. In the management phase, the lack of this prerequeriment was identified mainly in events related to the management of the construction site and problems with material storage, such as the cement stock not meeting standard specifications.

In the installations phase, it is noticed that two prerequirement stand out, "information" and "materials and components", representing each one $50 \%$ of the identified events. Regarding the information, there was a lack of conformity between the executed task and the projected one and a lack of clarity in the project specifications. Regarding materials and components, an example was the use of tube heating to replace the $90^{\circ}$ curve.

Finishing the data analysis, an evaluation, illustrated in Figure 9, was carried out between executive steps and the main impact caused by making-do waste, which showed that, in structure and masonry phases, impacts of "unfinished work" (29\% and 35\%, respectively) and "reduced quality" (29\% in both) were the main ones. The causes of which were the prioritization of other services, the use of inappropriate materials and equipment, the lack of planning, the complacency of the technical team and the lack of training with employees.

In the finishing phase, "rework" prevailed in its entirety as a consequence of the identified phenomena, because, to complete this step, the correction of defects in performed services was fundamental. Besides, the installation phase also had this impact 
highlighted $(83 \%)$ due to the presence of incompatibilities in projects and the lack of protection of components of the installations stage. Finally, in the management stage, "poor safety" (72\%) was highlighted as the main consequence of making-do waste, whose main causes were the lack of performance by the safety team and complacency of the engineering team.

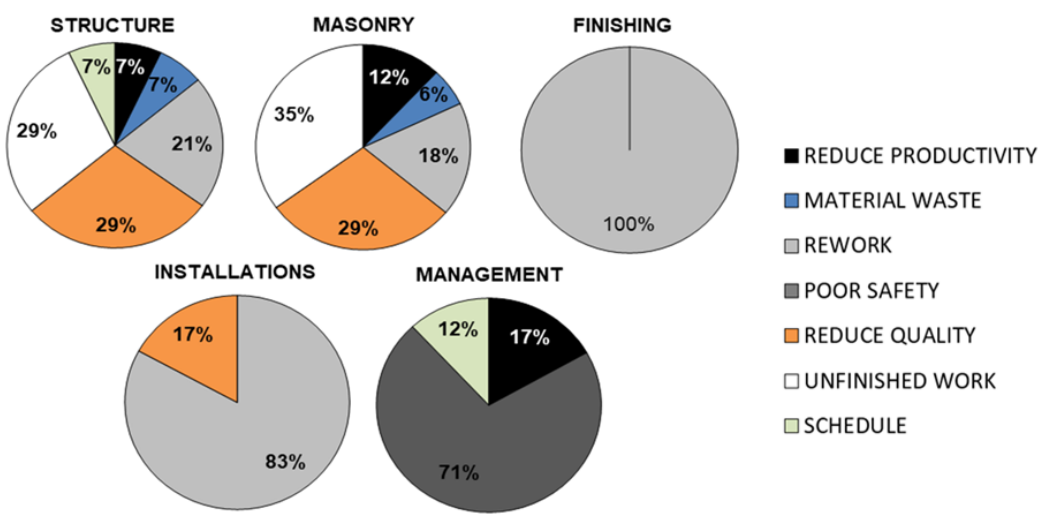

Figure 9: Impacts of making-do wastes by stages of execution

Figure 10 shows the risk analyzes in three construction companies, carried out according to Figure 3. Given this, Company A presents in its wastes $42.9 \%$ in the low and intermediate priorities. Company B has its highest percentage $(47.1 \%)$ in the high priority, but it can be said that there is a distribution of its wastes in all priorities. In company $\mathrm{C}$, it is observed that wastes are mostly within the intermediate priority, as it presents a percentage of $83.3 \%$.

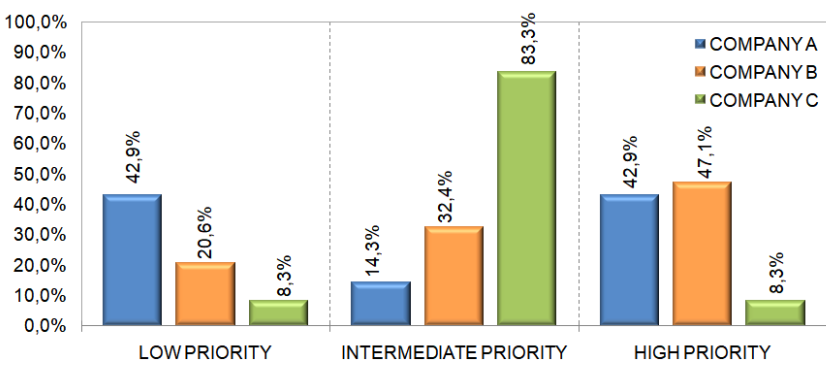

Figure 10: Risk analysis of making-do waste

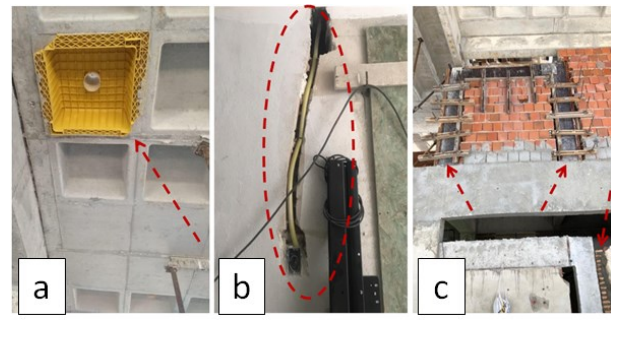

Figure 11: (a) Forms present in the ribbed slab cells; (b) Tears for the passage of pipes; (c) Broke the completed masonry

About low priority, a case analyzed in Company A is cited during the stripping of the structure, in which, at this stage, it is observed shape in the cells of the ribbed slab (Figure 11a). Thus, this event consists of a risk with an extremely remote probability and with very low severity. As for the intermediate priority, company $\mathrm{C}$ made tears for passage of pipes in the hall walls (Figure 11b), being considered as probable probability and moderate severity. At high priority, company B broke the completed masonry to execute part of the structure (Figure 11c), composing a remote probability risk, but with very high severity.

\section{CONCLUSIONS}

Based on analysis of data obtained in the scenarios observed at the construction sites, it was verified that "adjustment of the component" was the most significant category of 
making-do waste, with $40.3 \%$. From previous studies in the literature, Sommer (2010) highlighted "access and mobility" in the city of Porto Alegre, while Amaral et al. (2019) listed "sequencing" as the main waste category in Goiânia. Thus, it is observed that the categories of making-do waste depend on local occurrence.

The prerequeriment that generates most making-do wastes, among the construction companies studied, was "materials and components", with $73.6 \%$ of occurrence. Therefore, a throughout planning of the construction processes must be regarded with attention, so that minimum conditions to start, develop and finalize tasks are met, through prior knowledge and management of its prerequirement, thus aiming at reducing makingdo wastes. As for the analysis of the main impacts resulting from the identified makingdo wastes, rework was the most significant event with $38.9 \%$ in the wastes categories. This impact was very expressive, mainly in the finishing and installation stage.

A new impact could be seen during visits: schedule; since improvisations throughout the construction processes significantly interfered in the activity cycle period. Amaral et al. (2019) also advocate the addition of this impact when analyzing the construction scenario in the city of Goiânia. Thereafter, risk analysis plays a key role in making-do waste. It prioritizes services according to their degree of probability and severity, reflecting in the planning system adopted by each construction company.

However, considering that the data was limited to three construction sites, the results cannot be generalized for the city of Fortaleza, Brazil, and more studies are needed to obtain more representative parameters about making-do waste, identifying the relative importance of main causes for this type of waste according to the type of technologies used, cultural factors, existing regulations, particularities of construction processes and company's management, conditions of the work environment, among others.

\section{REFERENCES}

Amaral, T.G., Brandão, C.M., and Elias, K.V. (2019). "Investigation of wastes due improvisation in construction sites." Rev. Eletr. Eng. Civ. (REEC), 15 (1), 245-260.

Barbosa, G., Andrade, F., Biotto, C., and Mota, B. (2013)."Implementing Lean Construction effectively in a year in a construction project." Proc. 21st Ann. Conf. Int. Group for Lean Constr., Fortaleza, Brazil.

Brazilian Institute of Geography and Statistics - IBGE (2017). Pesquisa Anual da Indústria da Construção - PAIC (Annual Survey of the Construction Industry). $<$ www.ibge.gov.br/estatisticas/economicas/industria/9018-pesquisa-anual-daindustria-da-construcao.html? $=\& \mathrm{t}=$ resultados $>$. $($ Sep 15, 2019).

Cunha, M.P. (2004). Bricolage in Organizations. New Univ. of Lisboa. Lisboa, Portugal.

Emmitt, S., Pasquire, C., and Mertia, B. (2012). "Is good enough "making-do"?" Constr. Innov., 12 (3) 369-383.

Fireman, M.C.T. (2012). Proposed integrated control method between production and quality with measurement of wastes by making-do and packages informal. MS Thesis, Federal University of Rio Grande do Sul. Porto Alegre, Brazil.

Fireman, M.C.T., Formoso, C.T., and Isatto, E.L. (2013). "Integrating Production and Quality Control: monitoring making-do and unfinished work." Proc. 21st Ann. Conf. Int. Group for Lean Constr., Fortaleza, Brazil.

Formoso, C.T., De Cesare, C.M., Lantelme, E.M.V., and Soibelman, L. (1997). "Wastes in civil construction: concepts, classifications and their role in improving the sector." Federal University of Rio Grande do Sul. Porto Alegre, Brazil. 
Formoso, C.T., Sommer, L., Koskela, L.J., and Isatto, E.L. (2011). “An Exploratory Study on the Measurement and Analysis of Making-do in Construction Sites." Proc. 19st Ann. Conf. Int. Group for Lean Constr., Lima, Peru.

Formoso, C.T., Sommer, L., Koskela, L. and Isatto, E.L. (2017). "The identification and analysis of construction waste: perceptions of two Brazilian construction sites." Amb. Constr., 17 (2), 183-197, Porto Alegre, Brazil.

Government of the State of Ceará (2019). Ceará of PIB closes at $0.2 \%$ in the 1 st quarter of 2019 and the forecast for the year is of a rate of $1.34 \%$. $<$ www.ceara.gov.br/2019/06/19/pib-cearense-fecha-em-02-no-1o-trimestre-de-2019e-previsao-para-o-ano-e-de-uma-taxa-de-134/>. (Sep 15, 2019).

Grosfled-Nir, A., and Ronen, B. (1998). "The complete kit: modelling the managerial approach." Computers and Industrial Engineering, 34 (3) , 695-701.

Horman, M. Kenley, R. (2005). "Quantifying Levels of Wasted Time in Construction With Meta Analysis." J. Constr. Eng. and Manag., 131 (1), 52-61.

Koskela, L. (2004). "Making-do: the eighth category of waste." Proc. 12th Ann. Conf. Int. Group for Lean Constr., Elsinore, Denmark.

Leão, C.F. (2014). "Model Proposal for Integrated Production and Quality Control Using Information Technology." MS Thesis, UFRGS, Porto Alegre, Brazil.

Love, P.E.D. (2002)."Auditing the indirect consequences of rework in construction: a case based approach." Managerial Auditing J., 15 (30), 138-146.

Machado, R.L. (2003). The Systematization of Managerial Anticipations in Planning the Production of Civil Construction Systems. Thesis. Fed. Univ. of Santa Catarina. Florianópolis, Brazil.

Ohno, T. (1997). O Sistema Toyota de Produção: além da produção em larga escala (The Toyota Production System: in addition to large-scale production). Bookman; $150 \mathrm{p}$.

Ronen, B. (1992), “The complete kit concept", Int. J. Prod. Res., 30 (10), 57-66.

Rosenblum, A., Azevedo, V. Da S., Borges Junior, C.A., and Tavares, M.E. Da N. (2008). "Assessment Lean Thinking in civil construction - A strategic vision of implementation." Simpósio de Excelência em Gestão e Tecnologia (Symposium on Management and Technology Excellence). Rio de Janeiro, Brazil.

Santos, D. De G. (2004). Process Management Model in Civil Construction To Identify Facilitating Activities. Thesis, Federal Univ. of Santa Catarina. Florianópolis, Brazil.

Santos, P.R.R., and Santos, D. De G. (2017). "Investigation of wastes due to unfinished work and its impact on the cycle time of construction processes." Amb. Constr., 17 (2), 39-52, Porto Alegre, Brazil.

Saurin, T.A.(2002). "Safety and Production: a model for integrated planning and control." Thesis, Federal University of Rio Grande do Sul, Porto Alegre, Brazil.

Saurin, T.A., Formoso, C.T. and Guimaraes, L.B. (2004). "Safety and production: an integrated planning and control model." Constr. Mgmt and Econ., 22 (2), 159-169

Shingo, S. (1989). A Study of the Toyota Production System. Translated in English by Productivity Press. New York, USA.

Sommer, L. (2010). "Contributions to a method for identifying improvisation wastes in construction sites." MS Thesis, UFRGS, Porto Alegre, Brazil.

Viana, D.D., Formoso, C.F., and Kalsaas, B.T. (2012). "Waste in Construction: a systematic literature review on empirical studies." Proc. 20st Ann. Conf. Int. Group for Lean Constr., San Diego, USA. 